\title{
HKSA dan Penambatan Molekuler Senyawa Turunan Kumarin sebagai Anti Kanker Kolon
}

\author{
Yeni $^{1{ }^{1 *}, \text { Supandi }}{ }^{1}$, Yulianindra Khalishah ${ }^{1}$ \\ ${ }^{1}$ Fakultas Farmasi dan Sains, Universitas Muhammadiyah Prof. Dr. Hamka, Jakarta, Indonesia 13460 \\ *Email Korespondensi: yeni@uhamka.ac.id
}

doi: $10.29405 /$ j.bes/45-52121355

Received: 03 Maret 2018 | Accepted: 25 Mei 2018 | Published: 05 Juni 2018

\begin{abstract}
Abstrak
Tujuan: Senyawa turunan kumarin menunjukkan aktivitas anti koagulasi darah, menghambat kerja enzim, antimikroba, antibiotik, dan anti kanker dengan mengganggu sintesa DNA/RNA. Penelitian ini bertujuan memperoleh hubungan kuantitatif struktur-aktivitas senyawa turunan kumarin terhadap reseptor kanker kolon dengan pendekatan Hansch melalui analisis multilinear, untuk dapat melakukan modifikasi senyawa berdasarkan persamaan HKSA dalam usaha memperbesar potensi dan selektifitas obat. Metode: Deskriptor yang terpilih mewakili parameter elektronik,hidrofobik dan sterik. Penambatan molekul dilakukan dengan menggunakan Autodock Vina untuk menganalisa interaksi dari turunan kumarin terhadap enzim Topoisomerase II. Hasil: Hasil persamaan HKSA yang didapat telah tervalidasi dengan metode $L O O$ (Leave One Out) adalah $\mathrm{Log}_{\mathrm{IC}} \mathrm{I}_{50}=$ $4.047+(0.496 \times$ AM1_dipol $)+(-0.089 \times$ AM1_HOMO $)+(0.899 \times \log \mathrm{P}(\mathrm{o} / \mathrm{w}))+(0.903 \times \operatorname{logS})+(0.351 \times \mathrm{mr})$. Hasil penelitian menunjukkan $\mathrm{IC}_{50}$ prediksi dari senyawa yang di modifikasi (MOD2) dengan subtituen $\mathrm{NO}_{2}$ mempunyai aktivitas terbaik dengan $(\Delta G b i n d)$ terendah $(-8.8 \mathrm{Kcal} / \mathrm{mol})$ dan memiliki $\mathrm{IC}_{50}$ prediksi terkecil yaitu $1.0897 \mu \mathrm{M}$ dibandingkan $\mathrm{IC}_{50}$ lead compound (C14) yaitu $1.77 \mu \mathrm{M}$. Kesimpulan: Senyawa yang telah dimodifikasi (MOD2) memperlihatkan interaksi yang baik dengan reseptor kanker Topoisomerase II dengan menghasilkan energi bebas sebesar $-8,8 \mathrm{kcal} / \mathrm{mol}$.
\end{abstract}

Kata kunci: Antikanker Kolon; Hansch; HKSA; Penambatan Molekuler

\begin{abstract}
Background: Coumarin derivative compounds show anti-blood coagulation activity, inhibits the action of enzymes, antimicrobial, antibiotics, and anti-cancer by interfering the synthesis of DNA / RNA. This study aims to obtain quantitative structure-activity relationship, coumarin derivatives against colon cancer receptors with Hänsch approach through multilinear analysis, able to make modifications compounds based on QSAR equation in an attempt to enlarge the potency and selectivity of drugs. Methods: Descriptors were selected to represent the electronic, hydrophobic and steric parameters. Molecular Docking done by using Autodock Vina to analyze the interaction within coumarin derivatives and the topoisomerase II enzyme. Results: The results obtained QSAR equation has been validated by the method $\mathrm{LOO}$ (Leave One Out) is $\log \mathrm{IC}_{50}=-4.047+(0496 \times$ AM1_dipol) + ($0089 \times$ AM1_HOMO $)+(0899 \times \log \mathrm{P}(\mathrm{o} / \mathrm{w}))+(0.903 \times \operatorname{logs})+(0.351 \mathrm{x} \mathrm{mr})$. The results showed $\mathrm{IC}_{50}$ prediction of modificated compounds(MOD2) with NO2 substituents have the best activity with the lowest $\Delta$ Gbind $-8.8 \mathrm{kcal}$ / mol and has the smallest prediction $\mathrm{IC}_{50} 1.0897 \mu \mathrm{M}$ compared to $\mathrm{IC}_{50}$ lead compound (C14), that is $1.77 \mu \mathrm{M}$. Conclusions: The modified compound (MOD2) exhibits good interaction with Topoisomerase II cancer receptor by generating free energy of $-8.8 \mathrm{kcal} / \mathrm{mol}$.
\end{abstract}

Keywords: Colon Anti-cancer; Hansch; Molecular Docking; QSAR

(C) 2018 Bioeduscience. all rights reserved

\section{PENDAHULUAN}

Modifikasi senyawa dapat memperbesar potensi dan selektifitas suatu senyawa. Dalam mendesain suatu senyawa yang poten dan selektif, dapat dilakukan dengan beberapa metode salah satunya adalah metode in silico (komputasi) yaitu 
Hubungan kuantitatif Struktur Aktivitas (HKSA) dan penambatan Molekular (molecular Docking). Hubungan kuantitatif struktur aktivitas (HKSA) merupakan pendekatan yang menghubungkan struktur dan aktivitas biologi di dalam tubuh yang dinyatakan secara matematis (Siswandono \& Bambang, 2000), sedangkan penambatan molekular (molecular docking) adalah metode komputasi yang bertujuan meniru peristiwa interaksi suatu molekul ligan dengan protein yang menjadi targetnya pada uji in-vitro (Motiejunas \& Wade, 2006).

Kimia komputasi menurut IUPAC adalah suatu displin ilmu yang menggunakan metode matematika untuk menghitung sifat molecular atau untuk mensimulasi kelakuan sistem molecular (Waterbeemd et.al, 1997). Keuntungan dengan metode ini, peneliti dapat mengoptimasi aktivitas, geometri dan reaktivitas, sebelum senyawa disintesis secara eksperimental. Hal ini dapat menghindarkan langkah sintesis suatu senyawa yang membutuhkan waktu dan biaya yang mahal, tetapi senyawa yang dihasilkan tidak memiliki aktivitas seperti yang diharapkan.

Kanker Kolon, merupakan pertumbuhan sel kanker pada kolon. Kanker ini adalah satu dari bentuk kanker nomer 3 yang paling umum. (American Cancer Society, 2014). Banyak kanker usus besar yang diketahui berasal dari polip adenoma pada usus dan penumpukan tinja akibat konstipasi yang terlalu lama. Perkembangan polip tersebut kadang-kadang berkembang menjadi kanker. Terapi untuk kanker ini biasanya melalui operasi, yang biasanya diikuti dengan kemoterapi. Sekitar 75-95\% kasus kanker usus menyerang orang dengan resiko genetika tingkat rendah atau tidak sama sekali. (Watson \& Collins, 2011).

Dewasa ini salah satu senyawa yang dilaporkan memiliki aktivitas sebagai antikanker adalah derivat kumarin (Susilo \& Setyaningsih, 2018). H.M. Liu et.al dalam penelitiannya mengungkapkan senyawa turunan kumarin menunjukkan aktivitas sebagai anti kanker kolon, tetapi pada penelitian ini tidak dapat menggambarkan selektifitas senyawa pada sel kanker.
Pada penelitian ini, analisa hubungan kuantitatif struktur aktivitas (HKSA) dilakukan terhadap senyawa turunan kumarin dengan pendekatan hansch untuk mendapatkan rumus HKSA, dilanjutkan dengan modifikasi struktur turunan kumarin yang didesain berdasarkan rumus HKSA dan dilanjutkan dengan penambatan molekular pada reseptor kanker yg digunakan dalam penelitian ini yaitu enzim topoisomerase II, sehingga didapat suatu desain senyawa antikanker kolon yang lebih poten dan selektif. Penelitian ini diharapkan dapat menjadi acuan sintesis senyawa obat baru sebagai antikanker kolon.

\section{MATERI DAN METODE}

\section{Alat dan Bahan}

Dalam penelitian ini digunakan software offline yang terdiri dari ChemDraw 2004, HyperChem 8.0, Molecular Operating Environment (MOE 2009.10), SPSS 17 for windows, AutoDock Vina, AutoDock Tool version 1.5.6 (Scripps Research Institute), dan PyMol (Delano Scientific LLC).

Senyawa yang menjadi obyek dan digunakan dalam penelitian ini adalah 32 analog senyawa turunan kumarin yang tertera dari jurnal (Liu et.al, 2013). Struktur tiga dimensi enzim topoisomerase II yang berikatan dengan ligan etoposide diunduh dari Bank Data Protein melalui situs http://www.rcsb.org/pdb.

\section{Prosedur Penelitian}

\section{Preparasi Struktur 2 Dimensi}

Pembuatan struktur 2 dimensi 32 analog senyawa turunan kumarin dengan menggunakan program ChemDraw 2004, disimpan dalam format .mol.

\section{Optimasi Geometri}

Setelah 32 analog senyawa turunan kumarin di gambar dalam bentuk 2 dimensi, kemudian masing-masing analog dilakukan optimasi geometrinya dengan menggunakan program HyperChem 8.0. Adapun tahapannya dimulai dengan penambahan atom $\mathrm{H}$ dan pembentukan molekul model dengan menggunakan perintah 
Add $H \&$ model Build. Optimasi struktur molekul secara semi empiris dengan metode AM1 dengan gradient $0.1 \mathrm{kkal} / \AA$ dan disimpan dalam format *.mol untuk ketahapan selanjutnya.

\section{Perhitungan Deskriptor}

Perhitungan deskriptor dengan menggunakan aplikasi MOE 2009.10 Hasil perhitungan deskriptor tersebut selanjutnya dilakukan analisis statistik, sebelumnya beberapa senyawa analog yang memiliki nilai Z-Score lebih dari 2,5 dieliminasi (MOE 2009).

\section{Analisis Statistik}

Dilakukan analisis regresi multi linear dengan bantuan SPSS 17 for windows dengan variabel terikat $(\mathrm{Y})$ yaitu nilai aktivitas 32 analog senyawa turunan kumarin $\left(\log \mathrm{IC}_{50}\right)$ dan nilai variabel bebas (Xi) yaitu 12 nilai setiap deskriptor. Dari analisis regresi tersebut diperoleh beberapa persamaan yang menerangkan hubungan struktur dan aktivitas senyawa turunan kumarin. Setiap model persamaan akan memberikan kriteria statistik masing-masing. Pada penelitian ini, model persamaan yang diteruskan pengujian lebih lanjut yang memiliki koefiesen regresi $\left(r\right.$ dan $\left.r^{2}\right)$ dengan nilai $r \geq 0.9$.

\section{Validasi Model Persamaan}

Validasi bertujuan untuk mendapatkan nilai persamaan HKSA yang baik serta terbukti keterberulangannya. Cara pengujiannya dengan menggunakan validasi silang (cross valiation) teknik Leave One Out (LOO). Dengan pendekatan LOO, setiap senyawa terprediksi dihilangkan data aktivitas eksperimennya dalam analisis regresi linear. Kuadrat validasi silang LOO (q2) menjadi indikator performance dan stabilitas model (JinCan, 2008).

Dilakukannya validasi LOO ini akan diperoleh satu persamaan HKSA. Kriteria persamaan HKSA yang baik adalah yang memiliki nilai $\mathrm{r}^{2} \geq 0.8$ dan $q^{2} \geq 0.5$. Cara mendapatkannya dengan mengeluarkan data senyawa uji yang memiliki bias yang besar (outlier) dalam analisis regresi linear. Didapatkan rumus persamaan HKSA.

\section{Desain Senyawa Baru}

Langkah penting dalam mendesain senyawa baru, yaitu menentukan senyawa induk, memilih bagian rantai samping atau subsituen (R) senyawa induk untuk digantikan oleh subsituen baru dan menentukan daftar subsituen baru yang tentu saja harus berbeda dengan substituen senyawa induk. Setelah dibuat desain senyawa baru dengan memperhatikan rumus persamaan HKSA yang didapatkan, dilakukan kembali optimasi geometri dan perhitungan nilai deskriptor hingga didapatkan nilai IC $_{50}$ prediksi.

\section{Penambatan Molekular dengan AutoDock Vina}

Setelah didapatkan nilai $\mathrm{IC}_{50}$ prediksi, kemudian dilakukan penambatan molekularpada struktur baru tersebut untuk melihat aktivitasnya pada reseptornya. Penambatan molekular dilakukan dengan beberapa tahapan.

Makromolekul enzim Topoisomerase II diunduh dari Bank Data Protein melalui situs http://rcsb.org.pdb. Identitas molekul 3QX3 dalam format .pdb. Makromolekul protein kemudian dilakukan proses pemisahan molekul air dan ligan atau residu non standar. Proses ini dilakukan dengan menggunakan software Discovery StudioVisualizer 4.0. Hasil makromolekul yang telah dipisahkan disimpan dalam format.pdb. Selanjutnya, dilakukan proses optimasi makromolekul dengan menggunakan software Autodock Tool. Optimasi meliputi penambahan atom hidrogen dan pengaturan grid box parameter untuk menentukan lokasi penambatan molekul ligan. Hasil optimasi makromolekul disimpan dalam format .pdbqt.

Ligan yang digunakan sebagai pembanding adalah senyawa turunan kumarin yang memiliki nilai $\mathrm{IC}_{50}$. Sedangkan senyawa modifikasi turunan kumarin yang akan diuji dibuat dalam struktur 2D dengan menggunakan software Chem Draw 2004 dan disimpan dalam format .mol, kemudian dioptimasi geometri dengan menggunakan HyperChem 8.0 dan dikonversikan menjadi .pdb dengan software Discovery Studio Visualizer 4.0. Optimasi struktur ligan yang telah dibuat dengan menggunakan software Autodock Tools. Setelah itu, dilakukan penambatan molekuler ligan terhadap reseptor. 


\section{Analisis dan Visualisasi Penambatan Molekul}

Hasil kalkulasi penambatan dilihat pada output dalam format out.pdbqt. Pemilihan hasil penambatan dengan memilih ligan yang memiliki energi bebas Gibbs ( $\Delta$ Gbind) terendah. Data nilai energi ikatan setiap ligan dapat dilihat pada output hasil penambatan 'log.txt'.

Visualisasi posisi setiap ligan pada makromolekul dan asam amino yang terikat pada ligan dengan menggunakan software Pymol. Pymol akan menvisualisasi secara tiga dimensi. Pymol digunakan untuk melihat kecocokan situs tambat pada makromolekul dengan ligan.

\section{HASIL DAN PEMBAHASAN}

\section{Studi Hubungan Kuantitatif Struktur Aktivitas (HKSA)}

Tiga puluh satu senyawa percobaan dibuat dalam struktur 2D menggunakan ChemDraw dan disimpan dalam format .mol, kemudian optimasi dalam bentuk 3D menggunakan program Hyperchem kemudian dioptimasi struktur molekulnya secara semi empiris dengan metode AM1. Selanjutnya setiap model molekul disimpan dalam format *.mol. setelah itu dilakukan Pemilihan deskriptor.

Deskriptor yang dipilih adalah deskriptor yang dapat mewakili atau menjelaskan parameter dari persamaan Hansch, yakni: hidrofobik, elektronik, dan sterik. Perhitungan semua deskriptor dilakukan dengan menggunakan program MOE. Sebelum perhitungan nilai deskriptor, senyawa uji terlebih dahulu dimasukan dalam daftar molecular data base $\left({ }^{*} \mathrm{mdb}\right)$ dari software MOE. Daftar senyawa uji dalam mdb dimunculkan pada jendela Database Viewer program MOE 2009. Selanjutnya dilakukan perhitungan nilai deskriptor. Setelah semua nilai kedua belas (12) deskriptor didapatkan dari program MOE, selanjutnya menghitung nilai \$ZSCORE agar memperoleh persamaan QSARdengan kualitas statistik yang lebih baik. Dalam QSAR Tutorial MOE 2009 disebutkan bahwa data outlier adalah data yang memiliki nilai $\$ Z$-SCORE $\geq 2$. Setelah mengeleminasi data outlier dilakukan analisis statistik menggunakan SPSS hasil analisis multiregresi linear. Hasil yang didapat dari program SPSS adalah 8 model persamaan HKSA dengan nilai $r, r^{2}$, SE (Standar Error), dan deskriptor yang digunakan. Nilai $r$ (koefisien korelasi) menunjukan tingkat hubungan antara data aktivitas biologis pengamatan percobaan dengan data hasil perhitungan berdasarkan persamaan yang diperoleh dari analisa regresi. Sedangkan nilai $r^{2}$ menunjukan presentase aktivitas biologis yang dapat dijelaskan hubungannya dengan sifat fisika kimia yang digunakan (Siswandono 2008).

Tabel 1. Hasil Analisis regresi multi linier

\begin{tabular}{|c|c|c|c|c|}
\hline Model & Deskriptor & $\mathrm{R}$ & $\mathrm{r}^{2}$ & $\mathrm{SE}$ \\
\hline 1 & $\begin{array}{l}\text { vol, AM1_HF, AM1_HOMO, } \\
\text { M1_E,AM1_dipole, } \\
\text { AM1_Eele,mr }\end{array}$ & 0.966 & 0.933 & 0.1763 \\
\hline 2 & $\begin{array}{l}\text { vol, AM1_HOMO, glob, } \log \mathrm{P}(\mathrm{o} / \mathrm{w}), \mathrm{AM} 1 \_\mathrm{E}, \mathrm{AM} \text { 1_dipole, } \\
\text { ASA_H, logS, AM1_LUMO, AM1_Ee le,mr }\end{array}$ & 0.964 & 0.930 & 0.1679 \\
\hline 3 & $\begin{array}{l}\text { AM1_HOMO, glob, } \quad \log \mathrm{P}(\mathrm{o} / \mathrm{w}), \underset{\mathrm{AM} 1 \_\mathrm{E},}{\mathrm{AM} 1 \_\mathrm{d}} \\
\text { ipole,ASA_H, } \operatorname{logS}, \mathrm{AM} 1 \_L U M O, A M 1 \_E e l e, \mathrm{mr}\end{array}$ & 0.963 & 0.927 & 0.1614 \\
\hline 4 & $\begin{array}{l}\text { AM1_HOMO, glob, } \log \mathrm{P}(\mathrm{o} / \mathrm{w}), \mathrm{AM} 1 \_\mathrm{E}, \mathrm{AM} 1 \_\mathrm{d} \text { ipole, } \operatorname{logS} \text {, } \\
\text { AM1_LUMO, AM1_Eele, mr }\end{array}$ & 0.952 & 0.906 & 0.1742 \\
\hline 5 & $\begin{array}{l}\text { AM1_HOMO, glob, } \log \mathrm{P}(\mathrm{o} / \mathrm{w}), \quad \text { AM1_dipole, } \\
\text { AM1_LUMO, } \log \mathrm{S},\end{array}$ & 0.943 & 0.888 & 0.1808 \\
\hline
\end{tabular}


AM1_HOMO, glob, $\quad \log \mathrm{P}(\mathrm{o} / \mathrm{w}), \quad$ AM1_dipole, $\quad \operatorname{lo} \quad \mathrm{gS}, \quad 0.940 \quad 0.883 \quad 0.1774$ AM1_LUMO, mr

Pada tahap ini didapatkan nilai $\mathrm{R}$ pada masing masing persamaan. untuk kombinasi descriptor yang paling baik ditunjukkan pada persamaan 1 dengan descriptor jumlah descriptor yang dipilih sebanyak 12 descriptor dengan $\mathrm{R}$ 0.966 kriteria dari persamaan regresi adalah $\mathrm{R}$ harus $>0.9$ akan semakin baik bila nilai $\mathrm{R}$ semakin mendekati 1. Untuk dilanjutkan ke tahap selanjutnya dipilih persamaan dengan pertimbangan jumlah descriptor lebih sedikit dan nilai telah memenuhi kriteria statistic yakni $>0.9$. Persamaan yang diambil adalah persamaan 8 dengan nilai $\mathrm{R} 0.933$ karena semakin sedikit descriptor maka akan semakin memudahkan dalam perumusan HKSA dan pertimbangan untuk memodifikasi molekul. Rumus HKSA yang didapat yaitu $\log \quad \mathrm{IC}_{50}=-4.047+(0.496 \quad \mathrm{x}$ AM1_dipol $)+(-0.089 \times$ AM1_HOMO $)+(0.899$ $\mathrm{x} \log \mathrm{P}(\mathrm{o} / \mathrm{w}))+(0.903 \mathrm{x} \operatorname{logS})+(0.351 \times \mathrm{mr})$. selanjutnya dilakukan validasi terhadap persamaan HKSA yang didapat.

Validasi bertujuan untuk mendapatkan nilai persamaan HKSA yang baik serta terbukti keterberulangannya. Validasi menggunakan teknik validasi silang (cross validation). Cara pengujiannya dengan menggunakan validasi silang (cross valiation) teknik Leave One Out (LOO). Dengan pendekatan LOO, setiap senyawa terprediksi dihilangkan data aktivitas eksperimennya dalam analisis regresi linear. Kuadrat validasi silang LOO (q2) menjadi indikator performance dan stabilitas model nilai q2 harus lebih besar dari 0.5 yang menandakan keberulangan suatu metode (JinCan, 2008). Nilai RMSD $<1$ menunjukkan bahwa $\mathrm{IC}_{50}$ in vitro dengan $\mathrm{IC}_{50}$ prediksi tidak menunjukkan perbedaan yang berarti. maka diharapkan akan memberikan nilai yang mendekati keadaan real untuk molekul lain.
Hasil Validasi Metode LOO (leave One Out) adalah $\mathrm{q}^{2}$ sebesar 0.7328 dan RMSD sebesar 0.1449 . Dengan hasil diatas maka persamaan HKSA telah tervalidasi $\operatorname{LogIC}_{50}=-4.047+(0.496 \mathrm{x}$ AM1_dipol $)+(-0.089 \times$ AM1_HOMO $)+(0.899$ $\mathrm{x} \log \mathrm{P}(\mathrm{o} / \mathrm{w}))+(0.903 \mathrm{x} \operatorname{logS})+(0.351 \mathrm{x} \mathrm{mr})$ maka untuk mendapatkan suatu senyawa dengan $\mathrm{IC}_{50}$ lebih baik nilai AM1_dipol, $\operatorname{LogP}(\mathrm{o} / \mathrm{w}), \operatorname{LogS}$ dan $\mathrm{mr}$ harus kecil sedangkan AM1_HOMO harus besar. Berdasarkan rumus ini dapat dilakukan modifikasi pada molekul dengan menambahkan gugus yang lebih elektronegativ yang akan menambah sifat keelektronegatifan suatu molekul dan akan berdampak pada nilai AM1_HOMO.

\section{Desain Senyawa Baru}

Telah dipilih senyawa induk dengan nilai $\mathrm{IC}_{50}$ in vitro terkecil untuk dimodifikasi berdasarkan rumus HKSA yang telah tervalidasi, senyawa yang terpilih adalah senyawa nomer 14 dengan kode $\mathrm{C} 14$ dengan $\log \mathrm{IC}_{50}$ terkecil .

Tiga langkah penting dalam mendesain senyawa baru, yaitu menentukan senyawa induk, memilih bagian rantai samping atau subsituen (R) senyawa induk untuk digantikan oleh subsituen baru dan menentukan daftar subsituen baru yang tentu saja harus berbeda dengan substituen senyawa induk. Setelah dibuat desain senyawa baru dengan memperhatikan rumus persamaan HKSA yang didapatkan, dilakukan kembali optimasi geometri dan perhitungan nilai deskriptor hingga didapatkan nilai $\mathrm{IC}_{50}$ prediksi. 


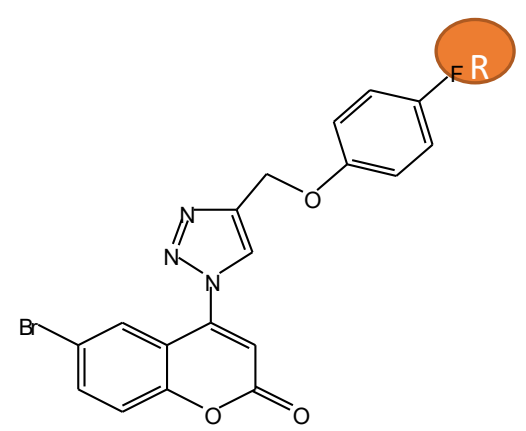

Gambar 1. Lead Compound C14: 6-bromo-4-(4((4-fluorophenoxy)methyl)-1H-1,2,3-triazol-1yl)-2H-chromen-2-one

Senyawa baru didesain berdasarkan rumus HKSA, maka subtituen yang dipilih adalah yang bersifat elektronegatif yakni $\mathrm{Br}, \mathrm{NO} 2, \mathrm{NH}$ hal ini dilakukan sebagai usaha memperbesar nilai keelektronegatifan dari senyawa lead compound
C14 Berikut desain modifikasi senyawa yang dilakukan.

Tabel 2. Modifikasi senyawa lead compound C14

\begin{tabular}{cc}
\hline Modifikasi & Subtituen \\
\hline 1 & $\mathrm{Br}$ \\
2 & $\mathrm{NO}_{2}$ \\
3 & $\mathrm{NH}_{2}$ \\
\hline
\end{tabular}

Tahapan selanjutnya dilakukan optimasi geometri terhadap senyawa termodifikasi. Selanjutnya dilakukan perhitungan descriptor. Descriptor yang digunakan adalah descriptor yang terpilih pada persamaan yang tervalidasi. Berikut adalah hasil Perhitungan descriptor untuk 3 senyawa yang telah dimodifikasi.

Tabel 3. Hasil nilai deskriptor senyawa termodifikasi

\begin{tabular}{clllllll}
\hline \multirow{2}{*}{ Modifikasi } & AM1_dipole & AM1_HOMO & $\log (\mathrm{o} / \mathrm{w})$ & $\operatorname{logS}$ & $\mathrm{Mr}$ & $\begin{array}{c}\mathrm{LOG} \mathrm{IC}_{50} \\
\text { IC }\end{array}$ & $\mathrm{IC}_{50}$ \\
& & & & & & PRED & PRED \\
\hline 1 & 3.6902 & -9.2839 & 4.5660 & -6.6332 & 10.3634 & 0.3622 & 2.3025 \\
2 & 3.5237 & -9.9345 & 3.6137 & -5.9297 & 10.1370 & 0.0373 & 1.0897 \\
3 & 4.64603 & -8.4714 & \multirow{2}{*}{3.0960} & -5.2637 & 9.9145 & 0.5210 & 3.3186 \\
\hline
\end{tabular}

Log $\mathrm{IC}_{50}$ lead compound $\mathrm{C} 14$ adalah 0.248 , dari 3 modifikasi yang dilakukan modifikasi yang ke 2 dengan menggunakan substituen $\mathrm{NO}_{2}$ yang menunjukkan hasil $\mathrm{Log} \mathrm{IC}_{50}$ paling baik. $\mathrm{NO}_{2}$ adalah substituent yang bersifat elektronegatif maka dengan mengganti rantai samping dengan subtituen $\mathrm{NO}_{2}$ dapat memperbesar sifat elektronegativitas total dari suatu senyawa dan berdasarkan persamaan akan meningkatkan kekuatan obat yang ditandai dengan semakin kecilnya nilai $\mathrm{IC}_{50}$.

Pada tahap akhir dilakukan penambatan molecular pada reseptor kanker yaitu enzim Topoisomerase II. Berikut adalah hasil molecular docking dari senyawa modifikasi yang memiliki $\mathrm{IC}_{50}$ paling baik.
Dari hasil penambatan molekuler didapat bahwa modifikasi 2 (MOD2) memiliki energi bebas $-8,8 \mathrm{kcal} / \mathrm{mol}$, nilai energi bebas MOD2 lebih kecil dibanding lead compound $\mathrm{C} 14$ dan senyawa pembanding yaitu doxorubicin. Asam amino yang berikatan dengan ligand sebagai ikatan hydrogen yaitu Asn790, Phe806, Gln 801 lebih banyak dibanding ikatan hydrogen yang terbentuk antara lead compound C14 dengan reseptor. Sedangkan untuk ikatan hidrofobik terdapat 8 asam amino yg berinteraksi dengan ligand yakni Val194, Ser827, Thr828, Asn798, Gln801, Glu1198, Gly804, Pro802. 


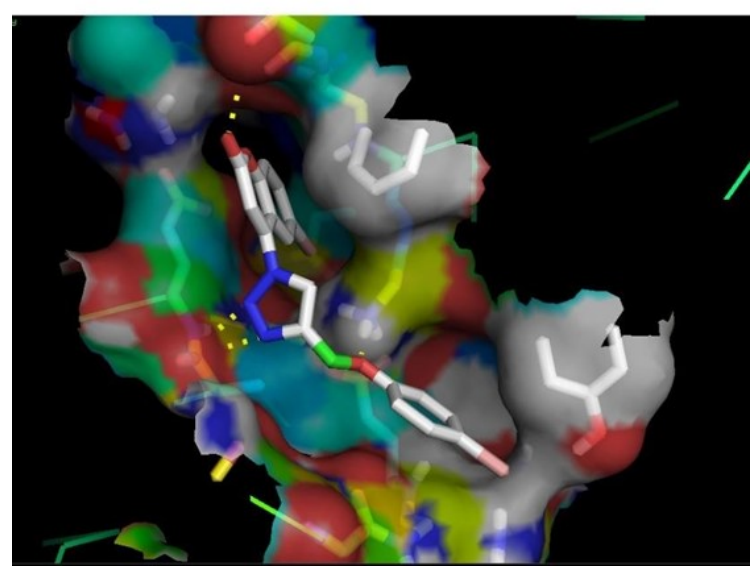

Gambar 2. Hasil Docking Topoisomerase II $><$ MOD2

Dapat dilihat bahwa senyawa yang dimodifikasi subtitusi dengan $\mathrm{NO}_{2}$ yang bersifat elektronegatif dapat meningkatkan potensi yang dapat dilihat dari nilai $\mathrm{IC}_{50}$ prediksi senyawa yang dimodifikasi yakni $1.0897 \mu \mathrm{M}$ yang lebih kecil dari $\mathrm{IC}_{50}$ lead compound yakni $1.7889 \mu \mathrm{M}$, serta dapat meningkatkan daya tambat ligan pada reseptor dapat dilihat dari banyaknya ikatan dan interaksi yang terbentuk antara senyawa yang termodifikasi dengan reseptor.

\section{KESIMPULAN}

Hasil analisa Hubungan kuantitatif strukturaktivitas dengan menggunakan metode Hansch dipengaruhi oleh beberapa descriptor diantaranya adalah AM1_Dipol AM1_HOMO, $\log \mathrm{P}(\mathrm{o} / \mathrm{w})$, LogS dan mr. dengan persamaan HKSA yang didapat:

$\log \mathrm{IC}_{50}=-4.047+(0.496 \times$ AM1_dipol $)+$ $(-0.089 \times$ AM1_HOMO $)+(0.899 \times \log \mathrm{P}(\mathrm{o} / \mathrm{w}))+$ $(0.903 \times \log S)+(0.351 \times \mathrm{mr})$. Senyawa dimodifikasi menggunakan subtitusi NO2. senyawa yang telah dimodifikasi berdasarkan rumus HKSA memiliki nilai $\mathrm{IC}_{50}$ yang lebih baik dibanding lead compound. 6-bromo-4-(4-((4nitrophenoxy)methyl)-1H-1,2,3-triazol-1-yl)2Hchromen-2-one merupakan hasil modifikasi yang memiliki nilai $\mathrm{IC}_{50}$ yang paling baik yaitu 1.0897 $\mu \mathrm{M}$. Senyawa yang telah dimodifikasi (MOD2) memperlihatkan interaksi yang baik dengan reseptor kanker Topoisomerase II dengan menghasilkan energi bebas sebesar $-8,8 \mathrm{kcal} / \mathrm{mol}$.

\section{DAFTAR PUSTAKA}

American Cancer Society. 2016. Colorectal cancer facts \& figures 2014-2016. www.cancer.org.

Anita Kurniawati RT (2011). Pengaruh Asam Asetil Salisilat terhadap Penurunan Prevalensi Kanker Kolorektal. Cermin Dunia Kedokteran 2011;38.

Arry Yanuar. 2012. Penambatan Molekular : Praktek dan Aplikasi Virtual Screening.

Aswad, M. 2009. Telaah Hubungan Kuantitatif Struktur-Aktivitas Senyawa Diterpen dari Bagore (Caesalpinia crista linn.) sebagai Antimalaria dan Interaksinya dengan Enzim Protease dari Plasmodium Falciparum secara in silico. Tesis tidak diterbitkan.

Bultink, P., Winter, H. D., Langenaeker, W. dan Tollenaere, J. P. 2004. Computational Medicinal Chemistry for Drug Discovery. Marcel Dekker, Inc., New York.

Ellis, G. P., M. N. Deborah, E. E. Schweizer, 1977. Chromenens, Chromanones and Chromones, The Chemistry of Heterocyclic Compounds. John Wiley \& Sons, New York.

Globocan (2012). Estimated Cancer Incidence, Mortality and Prevalence Worldwide in 2012. http://globocan.iarc.fr/Pages/fact_sheets_ cancer.aspx .

Liu et al. 2014. Synthesis And Biological Evaluation of 4-(1,2,3-triazol-1-yl) Coumarin Derivatives as Potential Antitumor Agents. Bioorganic \& medicinal chemistry letters. 24: 799-807.

Jin Can, C., Li, Q., Yong, S., LanMei, C., and KangCheng, Z. A QSAR Study and Molecular Design of Benzothiazole Derivatives as A Potent Anticancer Agents. Sci in China Ser B. 2008, Vol 51 No 2, 111-119.

Jong D. 2013. Buku Ajar Ilmu Bedah. dalam: Riwanto Ignatius, Hamami AH, Pieter John, Tjambolang Tadjuddin Ahmadsyah Ibrahim. Usus Halus, Appendiks, Kolon, dan Anorektum. Jakarta: EGC, 2013. 731-98.

Motiejunas, D., \& Wade, R. 2006. Structural, Energetics, and Dynamic Aspects of LigandReceptor Interactions. In J. B. Taylor \& D. J. Triggle (Eds.), Comprehensive Medicinal Chemistry II Volume 4: Computer-Assisted Drug Design. Elsevier. Vol. 4: 193-214).. 
Mukesh, Bachwani. 2011. Biological activities of 1,3,4-Oxadiazole: A review. Jaipur National University, India. Hlm 84-89.

Murray, R.D.H., and Brown J., Mendez. 1982. The Natural Coumarine. Jhon Willey and Son Ltd. New York.

Foye, W. 1996. Kimia Medisinal. Jilid II. Edisi Kedua. Yogyakarta: Gajah Mada.

Parish B, Ign. Riwanto, A. Maleachi, Kunsemedi S 2011. Report Incidence of Colorectal Cancer in Dr. Kariadi General Hospital Semarang 2009 - 2010. $1^{\text {st }}$ Makassar Colorectal Cancer Conference.

Pranowo, Harno Dwi. 2010. Pengantar Kimia Komputasi. Austrian-Indonesian centre for computational chemistry.

Robbins SL, Kumar VK. 2003. Neoplasia. In: Basic Pathology edisi7. Philadelphia: Saunders. hal. 166209.

Siswandono. 2000. Kimia Medicinal. Surabaya: Airlangga University Press. Halaman 124.

Siswandono, Bambang, S. 1998. Prinsip-Prinsip Rancangan Obat. Surabaya: Airlangga University Press. Halaman 161.

Siswandono dan Soekarjo, B., 2000, Kimia Medisinal, jilid II, Airlangga University Press, Surabaya, hal 346-353.

Susilo, \& Setyaningsih, M. 2018. Analysis of genetic diversity and genome relationships of four eggplant species (Solanum melongena L) using RAPD markers. Journal of Physics: Conf. Series, 948(012017), 1-6. doi:10.1088/17426596/948/1/012017

Van de Waterbeemd, H., Carter, R.E., Grassy, G., Kubinyi, H., Martin,Y.C., Tute, M.S., Willett, P., 1997. Computational Drug Design (IUPAC Recommendations. Hlm 1137.

Watson A J. Collins P. D. Colon Cancer: a Civilization disorder. Epub July 2011. www.ncbi. nlm.nih.gov. diakses 4 Februari 2016

Wu C-C, Li Y-C, Wang Y-R, Li T-K, Chan N-L. 2013. .On the"structural basis and design guidelines for type II topoisomerase-targeting anticancer drugs". Nucleic Acids Res. 41:10630-10640. doi: 10.1093/nar/gkt828. 